\title{
PROBLEMATIKA PENGATURAN CUTI KAMPANYE KEPALA DAERAH INCUMBENT DALAM PEMILIHAN KEPALA DAERAH DAN WAKIL KEPALA DAERAH DI INDONESIA
}

\author{
Jamaludin Ghafur \\ Fakultas Hukum Universitas Islam Indonesia \\ Email: Jamaludin.ghafur@uii.ac.id \\ Allan Fatchan Gani Wardhana \\ Pusat Studi Hukum Konstitusi \\ Fakultas Hukum Universitas Islam Indonesia \\ Email: allanfatchanganiw@gmail.com
}

\begin{abstract}
Abstrak
Pasal 70 ayat (3) UU Nomor 10/2016 tentang Pilkada mewajibkan kepala daerah incumbent untuk cuti jika yang bersangkutan akan mencalonkan kembali pada daerah yang sama. Terhadap aturan tersebut kemudian menimbulkan pro dan kontra, apakah aturan cuti kampanye bagi kepala daerah incumbent layak dipertahankan atau tidak. Setiap peraturan pasti memiliki kelebihan dan kelemahan termasuk peraturan tentang cuti ini terutama jika dikaitkan dengan tujuan dari pilkada itu sendiri. Rumusan masalahnya: Pertama, Bagaimana pengaturan persyaratan cuti kampanye bagi kepala daerah incumbent dalam UU Nomor 10/2016; Kedua, Apa kelebihan dan kelemahan adanya pengaturan persyaratan cuti kampanye bagi kepala daerah incumbent dalam pilkada. Penelitian ini merupakan penelitian yuridisnormatif dengan menggunakan dua pendekatan yaitu pendekatan kasus dan pendekatan perundang-undangan. Penelitian ini menyimpulkan, pertama pasal 70 ayat (3) UU 10/2016 telah menimbulkan problematika hukum. Kedua, terdapat kelebihan dan kelemahan terhadap aturan cuti kampanye. Salah satu kelebihannya ialah untuk membatasi kekuasaan kepala daerah agar tidak terjadi penyalahgunaan kekuasaan, sedangkan salah satu kelemahannya bahwa kewajiban untuk cuti dapat merugikan hak kepala daerah incumbent untuk bekerja menuntaskan amanah rakyat hasil pemilihan langsung serta merugikan rakyat pemilih.
\end{abstract}

Kata Kunci: Cuti Kampanye; Incumbent; Pilkada

\begin{abstract}
Article 70 paragraph (3) of Law No. 10 Year of 2016 on regional head elections obliges the incumbent to take a campaign leave if he/she will run back to the same area election. Each regulation certainly has strengths and weaknesses, especially if associated with the purpose of the election itself. The problem studied in this research are: First, how are the requirements taken for the campaign leave of the incumbent district head in Law No. 10 Year of 2016; Second, what are the advantages and
\end{abstract}


weaknesses of their requirements to take campaign leave for incumbent district head in the elections. This research is a normative and using two approaches, namely case approach and statute approach. This study concluded that the first paragraph of Article 70 (3) of Law 10/2016 has raised the problem of the law. Secondly, one of the advantages is to limit the power of the incumbent to prevent abuse of power, while one of the weaknesses is that the obligation to leave impair the right of the incumbent district head to complete the mandate of the people working directly and undermining the election results of the voters.

Keywords: Take a Campaign Leave; Incumbent; Regional Head Elections

\section{A. PENDAHULUAN}

Perbincangan dan diskursus mengenai pemilihan kepala daerah (pilkada) selalu dikaitkan dengan kerangka utama, yaitu prinsip demokrasi dan negara hukum. Bingkai demokrasi menjadi penting mengingat pilkada merupakan wujud dari demokrasi, sehingga prinsip dan nilai-nilai demokrasi harus disertakan dalam penyelenggaraannya. Sedangkan bingkai negara hukum memberikan jaminan hak asasi manusia didalamnya. Dalam paham negara hukum, jaminan hak asasi manusia merupakan salah satu elemen penting dan utama. Bahkan adanya jaminan hak asasi manusia juga sekaligus menjadi spirit dan ruh demokrasi itu sendiri sebagaimana dijamin oleh UUD NRI 1945.

Menguatkan pendapat itu, bahwa kedaulatan rakyat (demokrasi) tidak berdiri sendiri. Kehadirannya akan selalu dikaitkan dengan asas negara hukum (nomokrasi) (Junaidi, 2013: 15). Salah satu prinsip dalam negara hukum ialah adanya jaminan perlindungan hak asasi manusia. Oleh karena itu, pelaksanaan demokrasi harus didasarkan pada nilai-nilai hukum dengan menghormati hak asasi manusia sebagai basis utamanya. Berangkat dari prinsip demokrasi dan negara hukum inilah seharusnya aturan main terkait pilkada dirumuskan. Aturan terkait pilkada harus jelas dan tegas memuat prinsip-prinsip demokrasi dan hak asasi manusia, termasuk di sini yang terkait dengan persyaratan cuti kampanye kepala daerah incumbent dalam pilkada.

Terkait dengan aturan cuti kampanye kepala daerah incumbent dalam pilkada, secara spesifik diatur dalam Pasal 70 Undang-Undang Nomor 10 Tahun 2016 tentang Pilkada yang bunyi lengkapnya adalah sebagai berikut:

\section{Pasal 70}

1) Dalam kampanye, pasangan calon dilarang melibatkan:

a. pejabat badan usaha milik negara/badan usaha milik daerah;

b. aparatur sipil Negara, anggota Kepolisian Negara Republik Indonesia, dan anggota Tentara Nasional Indonesia; dan

c. Kepala Desa atau sebutan lain/Lurah dan perangkat Desa atau sebutan lain/perangkat Kelurahan.

2) Gubernur dan Wakil Gubernur, Bupati dan Wakil Bupati, Walikota dan Wakil Walikota, pejabat negara lainnya, serta pejabat daerah dapat ikut 
dalam kampanye dengan mengajukan izin kampanye sesuai dengan ketentuan peraturan perundang-undangan.

3) Gubernur dan Wakil Gubernur, Bupati dan Wakil Bupati, Walikota dan Wakil Walikota, yang mencalonkan kembali pada daerah yang sama, selama masa kampanye harus memenuhi ketentuan:

a. menjalani cuti di luar tanggungan negara; dan

b. dilarang menggunakan fasilitas yang terkait dengan jabatannya.

4) Cuti sebagaimana dimaksud pada ayat (3) bagi Gubernur dan Wakil Gubernur diberikan oleh Menteri Dalam Negeri atas nama Presiden, dan bagi Bupati dan Wakil Bupati serta Walikota dan Wakil Walikota diberikan oleh Gubernur atas nama Menteri.

5) Cuti yang telah diberikan sebagaimana dimaksud pada ayat (4), wajib diberitahukan oleh Gubernur dan Wakil Gubernur kepada KPU Provinsi, dan bagi Bupati dan Wakil Bupati, serta Walikota dan Wakil Walikota kepada KPU Kabupaten/Kota.

Melihat aturan di atas, bisa digarisbawahi bahwa dalam pasal 70 ayat (3) di atas itu mewajibkan kepala daerah incumbent untuk cuti jika yang bersangkutan akan mencalonkan kembali pada daerah yang sama. Terhadap aturan tersebut kemudian menimbulkan kubu pro dan kontra, apakah aturan cuti kampanye bagi kepala daerah incumbent layak dipertahankan atau tidak. Sebagaimana pada umumnya, setiap peraturan pasti memiliki kelebihan dan kelemahan termasuk peraturan tentang cuti ini terutama jika dikaitkan dengan tujuan dari pilkada itu sendiri.

Polemik terkait cuti kampanye bagi kepala daerah incumbent ini muncul pada awal Agustus lalu. Gubernur Daerah Khusus Ibukota (DKI) Jakarta, Basuki Tjahaja Purnomo alias Ahok mempersoalkan aturan terkait cuti kampanye dalam Pilkada. Ahok mengajukan uji materi (judicial review) ke Mahkamah Konstitusi dengan menggugat aturan Pasal 70 ayat (3) Undang-Undang Nomor 10 Tahun 2016 tentang Pilkada (Fachri Fachrudin, "Kaleidoskop 2016: Uji Materi yang Menyita Perhatian Sepanjang Tahun ini", http://nasional.kompas.com/read/2016/12/22/07360791/kaleidoskop.2016.uji.m ateri.yang.menyita.perhatian.sepanjang.tahun.ini, diakses pada Kamis, 22 Desember 2016, jam 07.36 WIB). Terhadap aturan tersebut, Ahok mengatakan bahwa sebenarnya ia setuju jika calon petahana harus cuti selama masa kampanye. Akan tetapi setelah dipertimbangkan, ia merasa keberatan dengan aturan terkait cuti kampanye karena masa kampanye Pilkada DKI Jakarta akan bersamaan dengan penyusunan Anggaran Pendapatan dan Belanja Daerah (APBD) tahun 2017. Selain itu, ia juga menegaskan tidak akan bisa maksimal dalam mengawasi birokrasi jika ia cuti. Adapun sesuai jadwal, untuk pilkada serentak 2017, masa cutinya dimulai 26 Oktober 2016 hingga 11 Februari 2017, atau kurang lebih sekitar empat bulan. Ahok menilai bahwa cuti empat bulan adalah waktu yang terlalu lama. Jika mengacu pada jadwal itu, praktis bahwa Ahok tidak bisa ikut dalam penyusunan APBD sekaligus tidak bisa mengawasi kinerja birokasi. 
Sebenarnya, argumentasi Ahok menggugat Pasal 70 ayat (3) UU Pilkada dengan alasan bahwa ia tidak akan bisa ikut dalam penyusunan APBD sekaligus tidak bisa maksimal mengawasi kinerja birokrasi adalah merupakan suatu alasan yang logis jika dibenturkan dengan efektivitas tata kelola pemerintahan. Meski jabatan kepala daerah yang nantinya cuti dapat digantikan oleh wakil kepala daerah ataupun pelaksana tugas, tetap saja sedikit-banyak akan berpengaruh terhadap kinerja pemerintahan. Disinilah stabilitas pemerintahan nantinya akan menjadi taruhan.

Namun di sisi yang lain, diaturnya cuti bagi kepala daerah incumbent yang akan maju lagi dalam pilkada sebenarnya sangat penting. Hal ini mengingat bahwa kepala daerah adalah jabatan politik dan jabatan publik yang bertugas memimpin birokrasi dan menggerakkan jalannya roda pemerintahan. Fungsi-fungsi pemerintahan terbagi menjadi perlindungan, pelayanan publik dan pembangunan (protective, public services, and development). Kepala daerah menjalankan fungsi pemerintahan itu. Dalam konteks struktur kekuasaan, kepala daerah adalah kepala eksekutif di daerah (Prihatmoko, 2005: 203)

Istilah jabatan publik mengandung pengertian bahwa kepala daerah menjalankan fungsi pengambilan kebijakan yang terkait langsung dengan kepentingan rakyat (publik), berdampak terhadap rakyat, dan dirasakan oleh rakyat (Prihatmoko, 2005: 203). Dengan adanya ketentuan cuti tersebut setidaknya dapat mencegah kepala daerah dengan peranannya yang besar dalam pengambilan kebijakan untuk menyalahgunakan berbagai kebijakan demi kepentingannya sendiri terutama untuk memenangkan proses kontestasi dalam pilkada yang sedang ia jalani.

Berdasarkan hal di atas, terdapat beberapa spesifik permasalahan yang menjadi fokus kajian artikel ini yaitu:

1. Bagaimana problematika pengaturan persyaratan cuti kampanye bagi kepala daerah incumbent dalam UU 10 Tahun 2016?

2. Apa kelebihan dan kelemahan adanya pengaturan persyaratan cuti kampanye bagi kepala daerah incumbent dalam pilkada?

\section{B. METODE PENELITIAN}

Jenis Penelitian ini adalah penelitian hukum normatif, karena peneliti melakukan penelitian dengan studi literatur dan peraturan perundang-undangan yang berhubungan dengan objek penelitian guna mencari jawaban atas masalah yang hendak diteliti. Sumber data yang digunakan dalam penelitian ini adalah bahan-bahan hukum yang terdiri dari bahan hukum primer, bahan hukum sekunder, dan bahan hukum tersier. Penelitian ini menggunakan teknik pengumpulan bahan hukum melalui metode penelitian library research yang terdiri dari buku-buku, jurnal ilmiah, media massa dan internet serta referensi lain yang relevan. Penelitian ini menggunakan teknik analisis bahan hukum deskriptif kualitatif yaitu pengelompokan dan penyesuaian data-data yang diperoleh dari suatu gambaran sistematis yang didasarkan pada teori dan pengertian hukum yang terdapat dalam 
ilmu hukum untuk menghasilkan kesimpulan yang signifikan dan ilmiah yang dapat menjawab rumusan masalah penelitian.

Penelitian ini menggunakan beberapa pendekatan, yakni: pertama, pendekatan kasus (case approach), yaitu digunakan untuk menelaah kasus-kasus yang berkaitan dengan masalah yang dihadapi yang telah menjadi putusan pengadilan dan telah mempunyai kekuatan hukum tetap (inkracht). Hal berkaitan dengan implikasi putusan MK terkait cikal bikal adanya pengatuan cuti kampanye bagi kepala daerah incumbent dalam pilkada. Kedua, pendekatan perundangundangan (statute approach), yaitu dengan menelaah peraturan perundangundangan yang berkaitan dengan permasalahan yang sedang dihadapi. Adapun peraturan perundang-undangan yang ditelaah adalah yang berkaitan dengan konsep pengaturan persyaratan cuti kampanye kepala daerah incumbent dalam pilkada. Melalui pendekatan ini diharapkan dapat menemukan jawaban terkait apa kelebihan dan kelemahan adanya pengaturan persyaratan cuti kampanye kepala daerah incumbent dalam pilkada.

\section{PEMBAHASAN}

1. Tinjauan Umum

\section{a. Negara Hukum \& Nomokrasi}

Konsep negara hukum mengalami pertumbuhan menjelang abad XX yang ditandai dengan lahirnya konsep negara hukum modern (welfare state), dimana tugas negara sebagai penjaga malam dan keamanan mulai berubah. Konsepsi nachwachterstaat bergeser menjadi welvarstaat. Negara tidak boleh pasif tetapi harus aktif turut serta dalam kegiatan masyarakat, sehingga kesejahteraan bagi semua orang terjamin (Huda, 2007: 55).

Pada negara modern "Welfare State" tugas pemerintah bukan lagi sebagai penjaga malam dan tidak boleh pasif tetapi harus aktif turut serta dalam kegiatan masyarakat sehingga kesejahteraan bagi semua orang terjamin. Dengan demikian pemerintah harus memberikan perlindungan bagi warganya bukan hanya dalam bidang politik tetapi juga dalam bidang sosial ekonomi sehingga kesewenangwenangan dari golongan kaya yang harus dicegah oleh pemerintah (Marbun dan Mahfud MD, 2009: 55). Oleh sebab itu tugas pemerintah diperluas dengan maksud untuk menjamin kepentingan umum sehingga lapangan tugasnya mencakup berbagai aspek.

Menurut Bagir Manan, konsepsi negara hukum modern merupakan perpaduan antara konsep negara hukum dan negara kesejahteraan. Di dalam konsep ini tugas negara atau pemerintah tidak semata-mata sebagai penjaga keamanan atau ketertiban masyarakat saja, tetapi memikul tanggungjawab mewujudkan keadilan sosial, kesejahteraan umum dan sebesar-besarnya kemakmuran rakyat (Manan, 1996: 16)

Selain itu, ide negara hukum, selain terkait dengan konsep rechstaat dan the rule of law, juga berkaitan dengan konsep nomocracy yang berasal dari perkataan nomos dan cratos. Perkataan nomokrasi itu dapat dibandingkan dengan demos dan 
cratos atau kratien dalam demokrasi. Nomos berarti norma, sedangkan cratos adalah kekuasaan. Maka, norma atau hukum dapat dibayangkan sebagai faktor penentu dalam penyelenggaraan kekuasaan. Karena itu, istilah nomokrasi itu berkaitan erat dengan ide kedaulatan hukum atau prinsip hukum sebagai kekuasaan tertinggi (Ashiddiqie 2006: 151).

Negara hukum sebagaimana dikembangkan oleh A.V. Dicey dapat dikaitkan dengan prinsip rule of law yang berkembang di Amerika serikat menjadi jargon the rule of law, and not of man. Bahwa sesungguhnya yang dianggap sebagai pemimpin adalah hukum itu sendiri, bukan orang. Plato dalam bukunya berjudul Nomoi (The Laws), di sana jelas tergambar bagaimana ide nomokrasi itu sesungguhnya telah sejak lama dikembangkan dari zaman yunani kuno (Ashiddiqie 2006: 151).

Konsep negara hukum mulai berkembang dengan pesat sejak akhir abad ke 19 dan awal abad ke 20. Immanuel Kant dan Friedrich Julius Stahl menyebut istilah Negara hukum di Eropa Barat Kontinental dengan istilah Rechtsstaat, sedangkan di negara-negara Anglo Saxon, A.V. Dicey menggunakan istilah Rule of Law (Ashiddiqie 2006: 152). Menurut F.J Stahl, konsep negara hukum yang disebutnya dengan istilah rechststaat itu mencakup empat elemen penting, yaitu: (1) Perlindungan terhadap hak asasi manusia; (2) Pembagian Kekuasaan; (3) Pemerintahan berdasarkan undang-undang; dan (4) Peradilan tata usaha negara (Ashiddiqie 2006: 152). Sedangkan unsur-unsur rule of law menurut Albert Van Dicey adalah tiga poin yaitu: (1) Supremasi aturan-aturan hukum; (2) Kedudukan yang sama dihadapan hukum; dan (3) Adanya jaminan terhadap hak-hak asasi manusia (Marbun, 2011 : 9).

Menurut perspektif sosiologis, gagasan the rule of law mengandung empat makna, yaitu (Huda, 2007: 55):

1. Otoritas harus diberi bentuk hukum dan bahwa kekuasaan harus dilaksanakan dengan cara-cara menurut hukum.

2. Hukum menjadi responsif terhadap kepentingan konsumen dan bertujuan untuk mendepersonalisasikan kekuasaan untuk menundukkan pelaksanaannya kepada aturan-aturan, sehingga melindungi warga negara dari tindakan sewenang-wenang penguasa.

3. Hukum tidak menentang kekuasaan, malahan dapat memperkuatnya agar tidak merosot menjadi pemaksa kehendak oleh penguasa.

4. Tidak netral terhadap kepentingan-kepentingan sosial, karena pemihakannya terhadap kelompok yang kurang beruntung secara politik, ekonomi, dan sosial.

Gagasan the rule of law mempunyai dimensi universalitas dan sekaligus relativitas. Dimensi universalitasnya ialah gagasan bahwa pelaksanaan kekuasaan dalam masyarakat harus tunduk kepada hukum, hal ini mempunyai implikasi normatif, yaitu (Huda, 2007: 58):

1. Mempunyai nilai yang berperspektif kerakyatan, yaitu melindungi warga negara terhadap pemerintah dan yang lemah serta miskin terhadap yang kuat serta kaya, dari sudut pandang warga negara yang lemah serta miskin. 
2. Penggunaan pendekatan konfliktual, bukan untuk melawan harmoni dan konsensus palsu, yang berarti dianut pandangan kepatuhan kondisional atas hukum dan otoritas, sehingga memberi ruang untuk beda pendapat dan beda penafsiran, serta kritik atas otoritas tidak ditindas.

Universalitas gagasan the rule of law juga dapat ditunjukkan oleh hasrat yang diperintah untuk diperlakukan baik dan adil oleh yang memerintah, meskipun kriterianya bisa berbeda dalam dimensi ruang dan waktu. Sedangkan dimensi relativitas the rule of law ialah bahwa tidak ada ukuran atau standar yang sama yang dapat dipakai oleh semua bangsa untuk menerapkan rule of law dalam praktik dan bisa memberikan hasil yang betul-betul memuaskan, karena the rule of law hanyalah merupakan prinsip-prinsip, bukan aturan-aturan konkret. Maka, yang dibutuhkan ialah kemauan politik dan komitmen moral untuk mewujudkan cita-cita the rule of law ( Huda, 2007: 58).

Keempat prinsip 'rechtsstaat' yang dikembangkan oleh Julius Stahl tersebut di atas pada pokoknya dapat digabungkan dengan ketiga prinsip 'Rule of Law' yang dikembangkan oleh A.V. Dicey untuk menandai ciri-ciri Negara Hukum modern di zaman sekarang. Bahkan, oleh "The International Commission of Jurist", prinsipprinsip Negara Hukum itu ditambah lagi dengan prinsip peradilan bebas dan tidak memihak (independence and impartiality of judiciary) yang di zaman sekarang makin dirasakan mutlak diperlukan dalam setiap negara demokrasi. Prinsip-prinsip yang dianggap ciri penting Negara Hukum menurut "The International Commission of Jurists" itu adalah: (1) Negara harus tunduk pada hukum; (2) Pemerintah menghormati hak-hak individu; dan (3) Peradilan yang bebas dan tidak memihak (Ashiddiqie 2006: 152).

Terdapat persamaan yang mendasar terhadap kedua jenis negara hukum tersebut di atas, keduanya saling menginginkan adanya perlindungan dan penghormatan hak asasi manusia yang telah diimpikan sejak berabad-abad lamanya dengan perjuangan dan pengorbanan yang besar. Faktor utama yang menjadi sebab timbulnya penindasan dan pelanggaran terhadap hak asasi manusia adalah karena terpusatnya kekuasaan negara secara mutlak pada satu tangan, yakni raja atau negara (absolute). Karena itu adanya keinginan untuk memisahkan atau membagikan kekuasaan kepada beberapa badan atau lembaga negara lainnya, merupakan salah satu cara untuk menghindari terjadinya pelanggaran terhadap hak-hak asasi manusia.

\section{b. Demokrasi}

Bagi negara-negara yang menganut demokrasi tentulah rakyat ditempatkan sebagai subjek yang sentral dalam menjalankan roda pemerintahan dengan garis dan prinsip dasar tertentu. Demokrasi sebagai sebuah sistem tentu memiliki prinsip-prinsip dasar. Prinsip-prinsip demokrasi menurut Masykuri Abdillah, terdiri dari persamaan, kebebasan, dan pluralisme. Prinsip persamaan memberikan penegasan, bahwa setiap warga negara baik rakyat biasa atau pejabat mempunyai persamaan kesempatan dan kesamaan kedudukan di muka hukum dan pemerintahan. Begitu pula dengan prinsip kebebasan, yang menegaskan bahwa 
setiap individu warga negara atau rakyat memiliki kebebasan menyampaikan pendapat dan membentuk perserikatan. Sedangkan prinsip pluralisme, memberikan penegasan dan pengakuan bahwa keragaman budaya, bahasa, etnis, agama, pemikiran dan sebagainya merupakan conditio sine qua non (sesuatu yang tidak bisa terelakkan) (Ubaidillah, 2000: 168). Sedangkan menurut Inu Kencana, prinsipprinsip demokrasi adalah: (1) Adanya pembagian kekuasaan (sharing power); (2) Adanya pemilihan umum yang bebas (general election); (3) Adanya manajemen pemerintahan yang terbuka; (4) Adanya kebebasan individu; (5) Adanya peradilan yang bebas; (6) Adanya pengakuan hak minoritas; (7) Adanya pemerintahan yang berdasarkan hukum; (8) Adanya pers yang bebas; (9) Adanya multi partai politik; (10) Adanya musyawarah; (11) Adanya persetujuan parlemen; (12) Adanya pemerintahan yang konstitusional; (13) Adanya ketentuan pendukung tentang sistem demokrasi; (14) Adanya pengawasan terhadap administrasi publik; (15) Adanya perlindungan HAM; (16) Adanya pemerintahan yang bersih (clean and good government); (17) Adanya persaingan keahlian (profesionalitas); (18) Adanya mekanisme politik; (19) Adanya kebijakan negara yang berkeadilan; dan (20) Adanya pemerintahan yang mengutamakan tanggungjawab (Ubaidillah, 2000: 168).

Sementara menurut Robert A. Dahl juga prinsip-prinsip demokrasi yaitu: (1) kontrol atas keputusan-keputusan pemerintah; (2) para penjabat yang dipilih selalu dari proses pemilihan yang dilakukan secara jujur; (3) adanya hak untuk memilih; (4) adanya hak untuk dipilih; (5) kebebasan warga negara untuk mengeluarkan dan menyatakan pendapat tanpa ancaman; (6) warga negara mempunyai hak untuk mendapatkan sumber-sumber informasi; dan (7) warga negara mempunyai hak untuk membentuk perkumpulan-perkumpulan atau organisasi (Dahl, 1982: 18). Prinsip-prinsip demokrasi terebut tentu bisa dijadikan pedoman bagi negara-negara yang menganut sistem demokrasi. Kaitannya dengan hal tersebut, Robert A. Dahl menggarisbawahi bahwa proses demokrasi yang ideal itu harus memenuhi lima kriteria secara utuh, yaitu (Dahl 1982: 10):

1. Persamaan hak pilih (equality in voting)

Dalam membuat keputusan kolektif yang mengikat, hak istimewa dari setiap warga negara seharusnya diperhatikan secara berimbang dalam menentukan keputusan terakhir.

2. Partisipasi efektif (effective participation)

Dalam seluruh proses pembuatan keputusan secara kolektif, termasuk tahap penentuan agenda kerja, setiap warganegara harus mempunyai kesempatan yang sama dan memadai untuk menyatakan hak-hak istimewanya dalam rangka mewujudkan kesimpulan terakhir.

3. Mendapatkan pemahaman yang jernih (gaining enlightened understanding) Dalam waktu yang dimungkinkan, karena keperluan untuk suatu keputusan, setiap warganegara harus mempunyai peluang yang sama dan memadai untuk melakukan penilaian yang logis demi mencapai hasil yang paling diinginkan.

4. Melaksaknakan kontrol terakhir terhadap agenda (exercising final control over the agenda) 
Masyarakat harus mempunyai kekuasaan eksklusif untuk menentukan soalsoal mana yang harus dan tidak diputuskan melalui proses-proses yang memenuhi ketiga kriteria sebelumnya. Dengan cara lain, tidak memisahkan masyarakat dari hak kontrolnya terhadap agenda dan dapat mendelegasikan kekuasaan kepada orang-orang lain yang mungkin dapat membuat keputusankeputusan lewat proses non demokratis.

5. Pencakupan orang dewasa (inclusion of adults)

Masyarakat harus meliputi semua orang dewasa dalam kaitannya dengan hukum, kecuali pendatang sementara.

Proses pembuatan keputusan yang demokratis adalah dengan didasarkan lima kriteria di atas. Bagi Robert A. Dahl, sulit untuk meyakini bagaimana orangorang dapat memerintah dirinya jika proses pembuatan keputusan yang mereka anut tidak memenuhi lima kriteria di atas. Demikian pula sama sulitnya untuk memahami bagaimana mereka dapat dituduh tidak memerintah dirinya sendiri selama proses-proses politik mereka telah memenuhi lima kriteria di atas secara utuh. (Dahl. 1982: 10). Jika salah satu saja diabaikan, maka demokratis atau tidaknya sebuah negara yang menganut demokrasi bisa dipersoalkan.

Adanya prinsip-prinsip tersebut di atas bisa dijadikan tolok ukur dalam melihat berbagai negara yang mengklaim sebagai negara demokrasi. Jadi, merujuk pada pendapat para ahli di atas, ketika kesempatan-kesempatan yang merupakan konsekuensi dari ukuran umum negara demokrasi tidak dijalankan, maka negara tersebut tidak dapat dikualifikasikan sebagai negara demokrasi. Bagi sebuah negara yang menganut demokrasi, prinsip-prinsip yang tersebut di atas wajib dipertimbangkan.

\section{c. Pemilihan Kepala Daerah}

\section{1) Pengaturan Pemilihan Kepala Daerah}

Pemilihan langsung selalu dijadikan tolok ukur untuk menentukan sebuah negara dapat dikatakan demokratis atau tidak. Demokrasi memang tidak sematamata ditentukan oleh ada tidaknya pemilihan oleh rakyat atas pemimpinpemimpinnya. Secara umum dikatakan bahwa pemilihan kepala daerah secara langsung itu lebih demokratis. Setidaknya ada dua alasan mengapa gagasan pemilihan langsung dianggap perlu. Pertama, untuk lebih membuka pintu bagi tampilnya kepala daerah yang sesuai dengan kehendak mayoritas rakyat sendiri. Kedua, untuk menjaga stabilitas pemerintahan agar tidak mudah dijatuhkan ditengah jalan. Dalam sejarahnya selama berlaku Undang-Undang Nomor 22 Tahun 1999 tentang Pemerintahan Daerah menunjukkan bahwa pilihan DPRD seringkali berseberangan dengan kehendak mayoritas rakyat di daerah (Huda, 2005: 204-205).

Proses pembentukan Undang-Undang Nomor 22 Tahun 1999 tentang Pemerintahan Daerah diselimuti oleh semangat reformasi di segala aspek kehidupan bernegara dan berlangsung secara cepat. Sehingga dalam perlawanannya, dirasakan ada substansi atau praktik penyelenggaraan yang kurang sesuai dengan jiwa dan semangat demokrasi dalam Negara Kesatuan Republik Indonesia. Kekurangan dalam Undang-Undang Nomor 22 Tahun 1999 tentang 
Pemerintahan Daerah telah disadari oleh para wakil rakyat yang duduk di MPR RI, sehingga melahirkan Ketetapan MPR Nomor IV/MPR/2000 tentang Rekomendasi Kebijakan dalam Penyelenggaraan Otonomi Daerah. Bersamaan dengan itu dalam Sidang Tahunan MPR RI Tahun 2000 telah dilakukan perubahan kedua UUD 1945 yang antara lain telah mengubah Bab IV tentang Pemerintahan Daerah dengan Pasal 18, Pasal 18A, dan Pasal 18B, sehingga dikeluarkannya Ketetapan MPR Nomor IV/MPR/2000 tersebut sejalan dengan perubahan UUD 1945 (Lutfi, 2010:118). Akhirnya Undang-Undang Nomor 22 Tahun 1999 tentang Pemerintahan Daerah mendesak untuk direvisi guna disinkronkan dengan hadirnya Pasal 18 UUD 1945 pasca perubahan.

Perubahan kedua UUD 1945 dalam Pasal 18 ayat (4) yang berbunyi “Gubernur, Bupati, dan Walikota masing-masing sebagai kepala pemerintah daerah provinsi, kabupaten, dan kota dipilih secara demokratis. Penggunaaan kata dipilih secara demokratis tersebut bersifat luwes dan memiliki dua makna yaitu pemilihan langsung maupun tidak langsung melalui DPRD kedua-duanya demokratis. Bila dicermati dari bunyi Pasal 18 ayat (4) tersebut memang tidak secara tegas mengatur bahwa Pemilihan Gubernur, Bupati, dan Walikota harus dilakukan dengan pemilihan langsung. Frasa "demokratis" dalam Pasal 18 ayat (4) UUD 1945 tersebut kemudian bisa ditafsirkan bahwa pemilihan kepala daerah itu dapat dilakukan dengan dua sistem pemilihan, baik pemilihan secara langsung maupun secara tidak langsung. Tentang bagaimana cara pemilihan kepala daerah itu sendiri kemudian hanya diserahkan kepada pembentuk undang-undang sebagaimana diatur pada pasal 18 ayat (7) UUD 1945 yang dalam hal ini adalah Presiden dan DPR. Hal ini juga dipertegas dengan Putusan MK No. 72-73/PUU-II/2004 yang memberi makna demokratis dalam pilkada. Kala itu, Mahkamah berpendapat bahwa UUD 1945 telah menetapkan pilkada secara demokratis baik langsung maupun cara-cara demokratis lainnya, yang terpenting harus berpedoman pada asas luber dan jurdil.

Sejarah terkait pengaturan pilkada di Indonesia cukup panjang. Dimulai dari Undang-Undang Nomor 22 Tahun 1999 tentang Pemerintahan Daerah; UndangUndang Nomor 32 Tahun 2004 tentang Pemerintahan Daerah; Undang-Undang Nomor 1 Tahun 2014 tentang Penetapan atas Perppu tentang Pemilihan Gubernur, Bupati, dan Walikota; Undang-Undang Nomor 8 Tahun 2015 tentang Pemilihan Gubernur, Bupati, dan Walikota; dan terakhir yaitu Undang-Undang Nomor 10 Tahun 2016 tentang Pemilihan Gubernur, Bupati, dan Walikota. Hadirnya berbagai revisi terhadap pengaturan pilkada ditujukan untuk menyempurnakan sistem penyelenggaraan pilkada itu sendiri dengan menempatkan pilkada secara langsung menjadi hal yang utama.

\section{2) Pilkada Praktik Demokrasi}

Keputusan untuk memilih sistem pilkada langsung bukan datang dengan tibatiba. Banyak faktor yang mendorong percepatan digunakannya sistem langsung tersebut, dengan semangat utamanya memperbaiki kehidupan demokrasi. Ada pun faktor-faktor pendorong tersebut antara lain yaitu, pertama, rakyat dapat berperan langsung, karena dalam sistem demokrasi, rakyat adalah pemilik kekuasaan sejati. 
Biarkan rakyat memilih pemimpin dan memengaruhi kebijakan-kebijakan publik di daerah yang menyentuh kepentingan mereka sendiri. Negara berkewajiban memfasiltasi rakyat mewujudkan kedaulatan tersebut. Kedua, pilkada langsung menghasilkan kepala daerah objektif, dalam arti siapapun yang terpilih itulah kehendak mayoritas rakyat. Hasil objektif tidak selalu identik dengan terpilihnya kepala daerah yang memiliki kapasitas dan kapabilitas yang baik dan dibutuhkan daerah. Namun hal itu harus diterima sebagai bagian dari proses pembelajaran demokrasi. Resiko semacam itu wajar terjadi dalam masyarakat yang belum rasional dan transaksional. Artinya, objektivitas pemilihan berbanding lurus dengan rasionalitas dan kekritisan rakyat (Prihatmoko, 2005: 26-27).

Pemilihan kepala daerah secara langsung sesungguhnya adalah suatu bentuk pembelajaran politik masyarakat yang sangat penting. Pembelajaran yang dimaksud adalah meningkatkan pembelajaran politik masyarakat daerah. Paling tidak masyarakat memahami realitas politik dan mengambil bagian secara aktif di dalamnya. Pilkada langsung juga memberi penguatan politik masyarakat lokal terutama dalam mengakses kebijakan pemerintah pemerintah (Muzani, 2016: 1-2).

Pemilihan kepala daerah secara langsung akan lebih mengefektifkan dan menjamin stabilitas penyelenggaraan roda pemerintahan daerah. Karena kepala daerah sebagai representasi pemerintahan yang dipilih secara langsung oleh rakyat dan reprentasi masyarakat lokal. Selain itu pilkada langsung juga menjamin terciptanya legitimasi pemerintahan daerah yang kuat sehingga tercipta pemerintahan yang efektif (Muzani, 2016: 1-2).

Selain itu, pilkada langsung merupakan mekanisme demokratis dalam rangka rekrutmen pemimpin di daerah, dimana rakyat secara menyeluruh memiliki hak dan kebebasan untuk memilih calon-calon yang didukungnya, dan calon-calon bersaing dalam suatu medan permainan dengan aturan main yang sama. Pilkada langsung dapat disebut pemilu apabila kedua prasyarat dasar tersebut diterjemahkan dengan berbagai tahapan kegiatan dan penunjang tahapan kegiatan yang terbuka (transparant) dan dapat dipertanggungjawabkan (accountable) (Prihatmoko, 2005: 109).

Prinsip utama dalam pembuatan tatacara dan mekanisme tahapan kegiatan dan penunjang tahapan kegiatan tersebut adalah menciptakan pilkada langsung dengan prosedur yang terduga (predictable procedure) dengan hasil yang tak terduga (unpredictable result). Artinya, ketentuan mengenai proses pemilihan dilakukan dengan tatacara dan mekanisme yang dapat diketahui dan diakses semua pemilih, partai politik, calon dan sebagainya untuk menjamin adanya transparansi dan akuntabilitas. Dengan proses tersebut, persaingan atau kompetisi yang berlangsung dalam pemilihan diharapkan berjalan bebas dan fair (free and fair) sesuai aturan main sehingga calon terpilih tidak diketahui atau ditentukan sebelumnya (Prihatmoko, 2005: 109-110). 


\section{Problematika Pengaturan Persyaratan Cuti Kampanye Bagi Kepala Daerah Incumbent Dalam Undang-Undang Nomor 10 Tahun 2016 Tentang Pemilihan Gubernur, Bupati, Walikota}

Perdebatan terkait kewajiban calon kepala daerah incumbent harus cuti dari jabatannya saat kampanye pilkada bukanlah sesuatu hal yang baru. Perdebatan itu mengemuka di ranah publik sejak adanya Putusan Mahkamah Konstitusi Nomor Perkara 17/PUU-VI/2008. Putusan MK tersebut lahir dari Pengujian UndangUndang Nomor 32 Tahun 2004 tentang Pemerintahan Daerah dan Undang-Undang Nomor 12 Tahun 2008 tentang Perubahan Kedua Atas Undang-Undang Nomor 32 Tahun 2004.

Melihat putusan MK tersebut ada satu hal penting yang pada akhirnya menjadi cikal bakal adanya aturan cuti untuk kepala daerah yang akan menjalani kampanye pilkada. Pasal 58 huruf q Undang-Undang Nomor 12 Tahun 2008 mensyaratkan bagi kepala daerah dan/atau wakil kepala daerah yang masih menduduki jabatan dan akan mencalonkan diri pada pemilihan kepala daerah dan/wakil kepala daerah harus mengundurkan diri sejak pendaftaran dan menurut Penjelasan Pasal 58 huruf q tersebut, pengunduran diri tersebut tidak dapat ditarik kembali.

Aturan tersebut digugat Sjachroedin SP yang berprofesi sebagai Gubernur Lampung Periode 2004-2009. Menurut Pemohon, dengan adanya Pasal 58 huruf q UU 12/2008 tersebut merugikan hak Pemohon untuk memegang masa jabatan sebagai Gubernur Lampung sampai dengan tanggal 2 Juni 2009. Selain itu, ketentuan yang terdapat dalam Pasal 58 huruf q UU 12/2008 juga menyebabkan adanya perlakuan yang tidak sama kepada Pemohon sebagai Kepala Daerah yang akan mencalonkan diri kembali sebagai kepala daerah pada masa jabatan berikutnya karena kewajiban mengundurkan diri dari jabatannya tidak diberlakukan kepada pejabat negara lainnya, yaitu Presiden dan Wakil Presiden, serta anggota Dewan Perwakilan Rakyat (DPR), Dewan Perwakilan Daerah (DPD), dan Dewan Perwakilan Rakyat Daerah (DPRD) sebagaimana ditentukan dalam Pasal 59 ayat (5) huruf h dan i UU 32/2004 (Putusan MK-RI Nomor Perkara 17/PUUVI/2008, hlm. 45-46). Terhadap pasal tersebut, MK Menyatakan Pasal 58 huruf q Undang-Undang Nomor 12 Tahun 2008 tentang Perubahan Kedua atas UndangUndang Nomor 32 Tahun 2004 tentang Pemerintahan Daerah bertentangan dengan UUD NRI 1945 serta tidak memiliki kekuatan hukum yang mengikat (Putusan MK-RI Nomor Perkara 17/PUU-VI/2008, hlm. 57).

Implikasi hukumnya, Kepala daerah petahana yang ingin maju lagi dalam pilkada tidak harus mengundurkan diri. Kekhawatiran bahwa kepala daerah petahana dapat memanfaatkan posisinya jika maju lagi dalam pilkada ditepis oleh MK dengan mengatakan "untuk menghindari konflik kepentingan (conflict of interest), calon yang sedang menjabat (incumbent) seharusnya cukup diberhentikan sementara sejak pendaftaran sampai dengan ditetapkannya calon kepala daerah terpilih oleh KPU sebagaimana ketentuan yang diberlakukan bagi pimpinan maupun anggota DPRD" (Putusan MK-RI Nomor Perkara 17/PUU-VI/2008, hlm. 55). 
Makna diberhentikan sementara itulah yang kemudian disandingkan dengan makna cuti. Sejak putusan inilah kemudian perdebatan dan ketentuan cuti bagi kepala daerah petahana yang ingin maju lagi dalam pilkada dimulai. Undang-Undang Nomor 10 Tahun 2016 akan menjadi landasan hukum bagi pelaksanaan pilkada serentak tahun 2017. Polemik terkait cuti kampanye bagi kepala daerah petahana ini muncul pada awal Agustus lalu. Gubernur Daerah Khusus Ibukota (DKI) Jakarta, Basuki Tjahaja Purnomo alias Ahok mempersoalkan aturan terkait cuti kampanye dalam Pilkada. Ahok yang sudah dipastikan akan maju lagi dalam Pilkada DKI Jakarta tahun depan mengajukan uji materi (judicial review) ke Mahkamah Konstitusi dengan menggugat aturan Pasal 70 ayat (3) Undang-Undang Nomor 10 Tahun 2016 tentang Pilkada. Bunyi lengkap pasal tersebut ialah:

\section{Pasal 70}

1) Dalam kampanye, pasangan calon dilarang melibatkan:

a. pejabat badan usaha milik negara/badan usaha milik daerah;

b. aparatur sipil Negara, anggota Kepolisian Negara Republik Indonesia, dan anggota Tentara Nasional Indonesia; dan

c. Kepala Desa atau sebutan lain/Lurah dan perangkat Desa atau sebutan lain/perangkat Kelurahan.

2) Gubernur dan Wakil Gubernur, Bupati dan Wakil Bupati, Walikota dan Wakil Walikota, pejabat negara lainnya, serta pejabat daerah dapat ikut dalam kampanye dengan mengajukan izin kampanye sesuai dengan ketentuan peraturan perundang-undangan.

3) Gubernur dan Wakil Gubernur, Bupati dan Wakil Bupati, Walikota dan Wakil Walikota, yang mencalonkan kembali pada daerah yang sama, selama masa kampanye harus memenuhi ketentuan:

a. menjalani cuti di luar tanggungan negara; dan

b. dilarang menggunakan fasilitas yang terkait dengan jabatannya.

4) Cuti sebagaimana dimaksud pada ayat (3) bagi Gubernur dan Wakil Gubernur diberikan oleh Menteri Dalam Negeri atas nama Presiden, dan bagi Bupati dan Wakil Bupati serta Walikota dan Wakil Walikota diberikan oleh Gubernur atas nama Menteri.

5) Cuti yang telah diberikan sebagaimana dimaksud pada ayat (4), wajib diberitahukan oleh Gubernur dan Wakil Gubernur kepada KPU Provinsi, dan bagi Bupati dan Wakil Bupati, serta Walikota dan Wakil Walikota kepada KPU Kabupaten/Kota.

Dengan demikian, pasal 70 ayat (3) di atas itu mewajibkan kepala daerah petahana untuk cuti jika yang bersangkutan akan mencalonkan kembali pada daerah yang sama. Terdapatnya ketentuan cuti seperti yang tertuang dalam pasal 70 ayat (2) dan ayat (3) di atas merupakan langkah positif untuk mewujudkan penyelenggaraan pilkada yang bersih dan demokratis. Ketentuan cuti tersebut juga berkaitan dengan persoalan keadilan. Keadilan merupakan cita-cita demokrasi dalam segala bentuknya. Dalam kampanye, keadilan sangat penting dan harus dijunjung tinggi. Keadilan menjadi dasar kompetisi yang sehat yakni "permainan di medan yang sama". Melalui keadilan, gesekan dan konflik antar pendukung dan antar calon bisa dihindarkan. Dengan demikian, keadilan menjadi alat sekaligus tujuan dalam kampanye (Prihatmoko, 2005: 260). Keadilan dalam kampanye 
pilkada langsung memiliki makna yang sangat luas. Keadilan dalam kampanye pilkada langsung diterjemahkan dengan beberapa cara, salah satunya cuti pejabat negara yang menjadi calon. Pejabat negara juga mempunyai hak untuk menjadi calon kepala daerah. Kewajiban menjalani cuti di luar tanggungan negara menjadi sangat penting untuk jalannya pemerintahan. Cuti merupakan upaya menjamin keadilan dalam kampanye. Melalui pemberlakuan cuti, akan mencegah mereka melakukan mobilisasi aparat pemerintahan dan penggunaan fasilitas dan anggaran pemerintah daerah (Prihatmoko, 2005: 263).

Terhadap aturan tersebut, Ahok mengatakan bahwa sebenarnya ia setuju jika calon petahana harus cuti selama masa kampanye. Akan tetapi setelah dipertimbangkan, ia merasa keberatan dengan aturan terkait cuti kampanye karena masa kampanye Pilkada DKI Jakarta akan bersamaan dengan penyusunan Anggaran Pendapatan dan Belanja Daerah (APBD) tahun 2017. Selain itu, ia juga menegaskan tidak akan bisa maksimal dalam mengawasi birokrasi jika ia cuti. Adapun sesuai jadwal, untuk pilkada serentak 2017, masa cutinya dimulai 26 Oktober 2016 hingga 11 Februari 2017, atau kurang lebih sekitar empat bulan. Ahok menilai bahwa cuti empat bulan adalah waktu yang terlalu lama. Jika mengacu pada jadwal itu, praktis bahwa Ahok tidak bisa ikut dalam penyusunan APBD sekaligus tidak bisa mengawasi kinerja birokasi (Allan Fatchan Gani Wardhana, "Cuti Kampanye Pilkada", $\quad$ http://berita.suaramerdeka.com/smcetak/cuti-kampanye-pilkada/, diakses 8 November 2016, pukul 13.30).

Sebenarnya, argumentasi Ahok menggugat Pasal 70 ayat (3) UU Nomor 10 Tahun 2016 dengan alasan bahwa ia tidak akan bisa ikut dalam penyusunan APBD sekaligus tidak bisa maksimal mengawasi kinerja birokrasi adalah merupakan suatu alasan yang logis jika dibenturkan dengan efektivitas tata kelola pemerintahan. Meski jabatan kepala daerah yang nantinya cuti dapat digantikan oleh wakil kepala daerah ataupun pelaksana tugas, tetap saja sedikit-banyak akan berpengaruh terhadap kinerja pemerintahan. Pada posisi inilah stabilitas pemerintahan nantinya akan menjadi taruhan.

Berdasarkan uraian di atas Pasal 70 ayat (3) UU Nomor 10 Tahun 2016 mengundang problematika hukum. Satu sisi dimaksudkan agar kepala daerah incumbent tidak menyalahgunakan jabatannya ketika kampanye, namun di sisi yang lain adanya aturan tersebut menghalang-halangi kepala daerah incumbent untuk bekerja sesuai amanah rakyat yang telah memilihnya untuk memimpin secara penuh selama lima tahun.

\section{Kelebihan Dan Kelemahan Adanya Pengaturan Persyaratan Cuti Kampanye Bagi Kepala Daerah Incumbent Dalam Pilkada}

Kepala daerah incumbent yang mencalonkan diri dalam Pilkada di daerah yang sama diwajibkan untuk menjalani cuti. Hal ini tertuang dalam Pasal 70 ayat (3) UU Nomor 10 Tahun 2016 yang bunyi lengkapnya "Gubernur dan Wakil Gubernur, Bupati dan Wakil Bupati, Walikota dan Wakil Walikota, yang mencalonkan kembali pada daerah yang sama, selama masa kampanye harus memenuhi ketentuan: a. 
menjalani cuti di luar tanggungan negara; dan b. dilarang menggunakan fasilitas yang terkait dengan jabatannya.

Pasal 70 ayat (3) UU Nomor 10 Tahun 2016 merupakan jalan tengah untuk menjawab perdebatan terkait pencalonan kepala daerah incumbent yang tidak harus mengundurkan diri dari jabatannya jika ingin maju lagi dalam pilkada. Sepanjang sejarah kontestasi pilkada, belum pernah terdapat aturan yang secara tegas mengatur terkait kewajiban mengundurkan diri bagi incumbent (petahana) jika ingin mencalonkan diri sebagai peserta pilkada. Pada perkembangannya, aturan yang terkait kewajiban mundur jika ingin mencalonkan diri sebagai kepala daerah dan wakil kepala daerah hanya berlaku bagi Pegawai Negeri Sipil (PNS), Anggota TNI/Polri, dan terakhir berlaku juga untuk Anggota DPR, Anggota DPD, dan Anggota DPRD.

Terhadap persyaratan pencalonan yang berbeda ini, banyak kalangan yang menilai bahwa aturan persyaratan dalam pencalonan pilkada sangat diskriminatif. Sebab diskriminatif karena hanya incumbent yang tidak mempunyai kewajiban mundur ketika mencalonkan diri, sedangkan unsur lain diwajibkan mengundurkan diri dari jabatannya. Lantas disimpulkan bahwa tidak adanya aturan yang mensyaratkan incumbent harus mundur adalah bertentangan dengan prinsip demokrasi dan hak asasi manusia.

Meski tidak ada aturan yang tegas mensyaratkan mundur bagi incumbent, namun pernah terdapat aturan terkait larangan calon kepala daerah yang ingin maju dalam pilkada tidak boleh memiliki konflik kepentingan dengan incumbent (petahana). Hal tersebut diatur dalam Pasal 7 huruf $r$ dan penjelasan Pasal 7 huruf $r$ Undang-Undang Nomor 8 Tahun 2015 tentang Pemilihan Gubernur, Bupati, dan Walikota. Memang aturan tersebut tidak spesifik mensyaratkan incumbent harus mengundurkan diri dari jabatannya jika ingin mencalonkan diri dalam pilkada, akan tetapi semangat aturan ini ialah mencegah praktik penyalahgunaan kekuasaan yang dilakukan oleh incumbent serta untuk menciptakan kompetisi yang fair antara calon yang berasal dari keluarga petahana (incumbent) dengan calon lain.

Tidak adanya aturan mengenai kewajiban mundur bagi incumbent menimbulkan problematika. Penjelasannya, pertama, karena petahana mempunyai akses terhadap kebijakan dan akses terhadap alokasi anggaran, sehingga dapat memberikan keuntungan pribadi untuk memenangkan pemilihan kepala daerah atau memenangkan kelompok-kelompoknya. Kedua, petahana secara alamiah memiliki berbagai fasilitas dan tunjangan yang melekat kepada dirinya sehingga, dalam melaksanakan tugas dan fungsinya, fasilitas dan tunjangan itu melekat terus menerus (Putusan MK-RI Nomor Perkara 33/PUU-XIII/2015: 128-129). Ketiga, karena sedang menjabat maka petahana memiliki keunggulan terhadap programprogram, terhadap kegiatan-kegiatan yang seluruhnya atau sebagian dapat diarahkan untuk memenangkan dirinya atau memenangkan dinastinya. Keempat, terkait dengan netralitas PNS di mana petahana mempunyai akses yang lebih besar untuk memobilisasi PNS guna memberikan dukungan yang menguntungkan dirinya. Ke-empat penjelasan tersebut tentunya menjadi warning bagi demokrasi Indonesia. 
Oleh karena itu, hadirnya Pasal 70 ayat (3) yang mewajibkan kepala daerah harus cuti saat kampanye merupakan jalan tengah untuk menghindarkan praktikpraktik negatif yang dapat dilakukan oleh kepala daerah saat mencalonkan diri lagi dalam pilkada. Namun demikian, pengaturan cuti kampanye pilkada bagi kepala daerah incumbent memiliki kelebihan dan kelemahan, antara lain:

\section{a. Kelebihan Pengaturan Cuti Kampanye Kepala Daerah Incumbent}

Kepala daerah incumbent wajib cuti jika ingin berlaga dalam kampanye pilkada. Adanya aturan yang mewajibkan kepala daerah petahana untuk cuti dalam kampanye sudah sesuai dan tidak perlu dipersoalkan. Ada empat kelebihan sekaligus terkait pentingnya cuti kampanye. Pertama, untuk membatasi kekuasaan kepala daerah agar tidak terjadi penyalahgunaan kekuasaan (abuse of power). Bagaimanapun Kepala daerah petahana mempunyai akses terhadap kebijakan dan akses terhadap alokasi anggaran, sehingga dapat memberikan keuntungan pribadi untuk memenangkan pilkada. Kedua, menghindarkan terjadinya konflik kepentingan (conflict of interest) yang berupa penggunaan berbagai fasilitas yang terkait dengan jabatannya. Petahana memiliki berbagai fasilitas dan tunjangan yang melekat kepada dirinya sehingga dalam melaksanakan tugas dan fungsinya, fasilitas dan tunjangan itu melekat terus menerus. Ketiga, mencegah petahana untuk "memobilisasi Pegawai Negeri Sipil (PNS). Netralitas PNS menjadi taruhan karena Petahana mempunyai akses yang lebih besar untuk memobilisasi PNS guna memberikan dukungan yang menguntungkan dirinya. Jika sampai PNS tidak netral maka akan mengganggu pelayanan terhadap masyarakat dan birokrasi menjadi tidak sehat. Keempat, untuk menjamin agar semua calon (di luar petahana) dengan calon petahana berangkat dari kondisi equal sehingga kompetisi dapat berlangsung secara fair (Putusan MK-RI Nomor Perkara 33/PUU-XIII/2015 : 128-129).

Djohermansyah Djohan, selaku ahli yang diutus Presiden Joko Widodo pada sidang uji materi Undang-Undang Nomor 10 Tahun 2016 tentang Pemilihan Gubernur, Bupati, dan Walikota, memaparkan bahwa sebaiknya cuti bagi calon petahana selama masa kampanye tetap dipertahankan karena lebih banyak manfaatnya daripada mudaratnya. Cuti diharapkan membuat petahana bisa tahan dari abuse of power. Penyalahgunaan kekuasaan itu, menurut Djohermansyah, modusnya mulai dari penyelewengan dana bantuan sosial, penyelewengan Anggaran Pendapatan dan Belanja Daerah, penyalahgunaan perizinan, hingga politisasi pegawai negeri sipil. Mantan Dirjen Otonomi Daerah Kementerian Dalam Negeri itu juga menyampaikan bahwa nantinya Menteri Dalam Negeri akan memilih pejabat dari Kemendagri yang terpandang dan terbebas dari politik kepentingan untuk menjabat pelaksana tugas (Plt) gubernur selama masa kampanye. Di dalam Permendagri Nomor 74 Tahun 2016, Pelaksana Tugas (Plt) gubernur diberi mandat yang lebih besar dari sebelumnya. Bahkan, bisa menandatangani Perda APBD. Hal ini sekaligus menjawab kekhawatiran Ahok terhadap keberlanjutan APBD DKI 2017 (Kurnia Sari Aziza, "Perdebatan Ahok dan Utusan Jokowi Soal Cuti Kampanye Petahana", 
http://sains.kompas.com/read/2016/10/07/09520321/perdebatan.ahok.dan.utus an.jokowi.soal.cuti.kampanye.petahana, diakses pada Jumat, 10 Oktober 2016).

Aturan terkait cuti kampanye di atas juga sekaligus memiliki korelasi dengan aspek moral. Mengutip Benny Susetyo, ia mengatakan bahwa Orang bermoral adalah orang yang menjalankan hukum secara konsisten; orang yang taat pada apa yang digariskan oleh hukum. Inkonsistensi dalam menjalankan hukum menandakan adanya moralitas yang absurd (kosong). Padahal, moralitas bukanlah sesuatu yang absurd tetapi sebuah acuan untuk membangun realitas Indonesia Baru sebagai negara hukum (rechtstaat). Bila moralitas sudah tidak dianggap penting; kepatuhan bersama terhadap hukum sudah tidak ada; sanksi-sanksi sosial dan hukum yang mesti diberikan kepada pelanggarnya sudah tidak ada; maka bangsa Indonesia sudah jauh dari sebutan bangsa yang beradab (Susetyo, 2004: 165). Maka, sudah seharusnya norma Pasal 70 ayat (3) yang berkaitan dengan cuti kampanye harus ditaati dan dijalankan secara konsekuen.

\section{b. Kelemahan Pengaturan Cuti Kampanye Kepala Daerah Incumbent}

Meski kebijakan Kepala daerah incumbent wajib cuti jika ingin berlaga dalam kampanye pilkada memiliki beberapa kelebihan, tetap saja ada beberapa kelemahan yang mengiringinya. Setiap kebijakan tentu memiliki kelebihan dan kelemahan. Beberapa kelemahan terkait adanya pengatuan cuti kampanye bagi kepala daerah incumbent antara lain: Pertama, secara filosofi sumpah jabatan, kewajiban untuk cuti dapat merugikan hak kepala daerah incumbent untuk bekerja menuntaskan amanah rakyat hasil pemilihan langsung serta merugikan rakyat pemilih. Kepala Daerah incumbent berpotensi dirugikan haknya dengan diwajibkan cuti selama kurang lebih 4 bulan sampai dengan 6 bulan apabila pemilihan Kepala Daerah. Padahal prinsipnya jabatan gubernur, adalah memerintah demi memajukan kesejahteraan umum, sebagaimana dinyatakan dalam Pembukaan Undang-Undang Dasar 1945. Gubernur selaku kepanjangan tangan dari presiden berpandangan bahwa sudah selayaknya pejabat yang dipilih secara langsung oleh rakyat melaksanakan tugasnya secara penuh di dalam masa 5 tahun sejak dilantik. Ini sejalan dengan ketentuan Undang-Undang Dasar 1945 Pasal 7 yang mengatur bahwa presiden dan wakil presiden memegang jabatan selama 5 tahun. Dengan demikian, Pasal 7 Undang-Undang Dasar Tahun 1945 juga sesungguhnya telah memberikan jaminan konstitusional bahwa hak dan kewenangan Gubernur incumbent tidak boleh dikurangi untuk menjabat sampai dengan masa periodenya berakhir. Kedua, kebijakan cuti kampanye bagi kepala daerah incumbent akan mengganggu efektivitas tata kelola pemerintahan dalam melayani masyarakat. Sebagai contoh, dalam pencalonan Pilgub DKI, bahwa Pemerintah Provinsi DKI Jakarta sedang menjalankan banyak program prioritas yang perlu dilanjutkan berkesinambungan. Adapun program-program prioritas yang dimaksud antara lain (Risalah Sidang MK-RI Perkara Nomor 60/PUU-XIV/2016: 12):

1) Pengembangan sistem transportasi, yakni permbangunan angkutan massal berbasis (suara tidak terdengar jelas) dan program angkutan massal yang berbasis jalan; 
2) Antisipasi banjir, rob, dan genangan yakni pembangunan prasarana dan sarana pengendali banjir. Terutama mengingat bahwa akan ada puncak fenomena alam La Nina pada Februari tahun 2017;

3) Peningkatan kualitas lingkungan perumahan dan pemukiman kota melalui program penyediaan perumahan rakyat; dan

4) Peningkatan kualitas kesehatan masyarakat melalui program jaminan pemeliharaan kesehatan daerah beserta dengan pembiayaannya, program peningkatan sarana dan prasarana kesehatan, program pembinaan upaya kesehatan, serta program pengendalian penyakit, dan penyehatan lingkungan.

Ketiga, pemberlakuan cuti petahana dapat melemahkan fungsi pengawasan yang dilakukan oleh Gubernur. Fungsi pengawasan gubernur menjadi melemah manakala digantikan oleh Pelaksana Tugas. Berdasarkan contoh kasus di atas, Fungsi pengawasan Gubernur tentunya sangat dibutuhkan untuk memastikan terlaksananya proses penganggaran yang baik untuk program-program prioritas tersebut. Dalam kasus Ahok, Program yang bermanfaat bagi masyarakat DKI Jakarta yang merupakan warga di dalam wilayah tugas Gubernur Incumbent dan sekaligus calon pemilih dalam pemilihan serentak 2017 ini penting agar terlaksana baik agar dapat dilaksanakan di periode kepemimpinan kepala daerah DKI Jakarta berikutnya.

Adanya kelebihan dan kelemahan dalam kebijakan cuti kampanye bagi kepala daerah incumbent merupakan perdebatan yang menarik. Terlebih aturan cuti kampanye bagi kepala daerah incumbent sedang diuji ke Mahkamah Konstitusi. Terlepas apapun putusan MK, penulis mempunyai gagasan untuk menengahi pertentangan antara kelebihan dan kelemahan adanya pengaturan persyaratan cuti kampanye bagi kepala daerah incumbent dalam pilkada. Terhadap persoalan kampanye, perlu adanya perbedaan konsep kampanye yang dilakukan oleh kepala daerah incumbent dengan kepala daerah yang bukan incumbent. Kepala daerah incumbent dalam masa kampanye tidak perlu cuti, melainkan nantinya dalam kampanye cukup berkampanye dengan cara menunjukkan kinerja dan bekerja untuk rakyat didaerah tanpa harus terlibat dalam kampanye dengan model memakai atribut atau hal sejenis lainnya. Jadi, kepala daerah incumbent tidak perlu cuti karena justru dengan cuti tata kelola pemerintahan dapat terganggu, terlebih terkait dengan keputusan-keputusan yang strategis yang harus segera diputuskan oleh kepala daerah. Sedangkan kampanye untuk kepala daerah yang bukan incumbent, kampanye dilaksanakan dengan menggunakan model atribut kampanye.

Pertimbangan antara kelebihan dan kelemahan serta gagasan penulis tersebut dapat dijadikan pertimbangan oleh hakim MK dalam memutus gugatan Pasal 70 ayat (3) UU 10/2016. Penulis berpandangan bahwa MK harus menguatkan titik taut antara cuti kampanye dengan upaya mewujudkan pilkada yang bersih, demokratis, dan akuntabel. 


\section{KESIMPULAN DAN SARAN \\ 1. Kesimpulan}

Berdasarkan analisis dan pembahasan di atas, maka dapat ditarik kesimpulan sebagai berikut:

a. Adanya Pasal 70 ayat (3) UU 10/2016 menimbulkan problematika hukum dalam pilkada. Di satu sisi dimaksudkan agar kepala daerah incumbent tidak menyalahgunakan jabatannya ketika kampanye, namun disisi yang lain adanya aturan tersebut menghalang-halangi kepala daerah incumbent untuk bekerja sesuai amanah rakyat yang telah memilihnya untuk memimpin secara penuh selama lima tahun.

a. Pengaturan terkait persyaratan cuti kampanye bagi kepala daerah incumbent dalam pilkada mempunyai kelebihan dan kelemahan. Adapun kelebihannya ialah untuk membatasi kekuasaan kepala daerah agar tidak terjadi penyalahgunaan kekuasaan; menghindarkan terjadinya konflik kepentingan (conflict of interest) yang berupa penggunaan berbagai fasilitas yang terkait dengan jabatannya; mencegah petahana untuk "memobilisasi Pegawai Negeri Sipil (PNS); dan untuk menjamin agar semua calon (diluar petahana) dengan calon petahana berangkat dari kondisi equal sehingga kompetisi dapat berlangsung secara fair. Adapun kelemahannya antara lain adalah, kewajiban untuk cuti dapat merugikan hak kepala daerah incumbent untuk bekerja menuntaskan amanah rakyat hasil pemilihan langsung serta merugikan rakyat pemilih; Kebijakan cuti kampanye bagi kepala daerah incumbent akan mengganggu efektivitas tata kelola pemerintahan dalam melayani masyarakat; dan dapat melemahkan fungsi pengawasan kepala daerah dalam mengawasi birokrasinya.

\section{Saran}

Berdasarkan kesimpulan di atas, saran-saran yang dapat direkomendasikan dalam penelitian ini dapat dirinci sebagai berikut:

a. Bagi Gubernur dan Wakil Gubernur, Bupati dan Wakil Bupati, Walikota dan Wakil Walikota, yang mencalonkan kembali pada daerah yang sama, selama masa kampanye harus taat dengan norma Pasal 70 ayat (3) UU Nomor 10 Tahun 2016 dengan menjalani cuti di luar tanggungan negara dan dilarang menggunakan fasilitas yang terkait dengan jabatannya.

b. Bagi Pemerintah, DPR, dan MK harus harus melakukan telaah terhadap norma Pasal 70 ayat (3) UU Nomor 10 Tahun 2016 baik telaah peraturannya maupun implementasinya di lapangan demi terwujudnya penyelenggaran pilkada yang bersih, akuntabel, dan demokratis. 


\section{DAFTAR PUSTAKA}

\section{A. BUKU}

Asshiddiqie, Jimly (2005). Hukum Tata Negara dan Pilar-Pilar Demokrasi. Jakarta: Konstitusi Press.

(2011). Konstitusi dan Konstitusionalisme Indonesia. Jakarta: Sinar Grafika Offset.

Alim, Muhammad (2001). Demokrasi dan Hak Asasi Manusia Dalam Konstitusi Madinah dan UUD 1945. Yogyakarta: UII Press.

Dahl, Robert A. (1982). Dilemmas of Pluralist Democracy: Autonomy and Control. New Heaven and London: Yale University Press.

Gaffar, Afan (2001). Politik Indonesia Transisi Menuju Demokrasi. Yogyakata: Pustaka Pelajar.

Gaffar, Janedri M (2012). Demokrasi Konstitusional. Jakarta: Konpress.

Huda, Ni'matul (2005). Otonomi Daerah Filosofi Sejarah Perkembangannya dan Problematika. Yogyakarta: Pustaka Pelajar.

(2006). Hukum Tata Negara Indonesia. Jakarta: PT Raja Grafindo Persada.

Yogyakarta: UII Press.

(2009). Hukum Pemerintahan Daerah. Bandung: Nusa Media.

Junaidi, Veri 2013. Mahkamah Konstitusi Bukum Mahkamah Kalkulator. Jakarta: Themis Books.

Lutfi, Mustafa (2010). Hukum Sengketa Pemilukada Di Indonesia Gagasan Perluasan Kewenangan Konstitusional Mahkamah Konstitusi. Yogyakarta: UII Press.

Manan, Bagir (1996). Politik Perundang-undangan dalam Rangka Mengantisipasi Liberalisasi Perekonomian. Lampung: FH Unila.

Marbun, S.F (2011). Peradilan Administrasi Negara dan Upaya Administarif Di Indonesia. Yogyakarta: FH UII Press.

Marbun, S.F dan MD, Mahfud (2009). Pokok-Pokok Hukum Administrasi Negara. Yogyakarta: Penerbit Liberty.

Prihatmoko, Joko J (2005). Pemilihan Kepala Daerah Langsung: Filosofi Sistem Dan Problema Penerapan di Indonesia. Yogyakarta: Pustaka Pelajar.

Saifudin (2009). Partisipasi Publik Dalam Pembentukan Peraturan Perundangundangan. Yogyakarta: FH UII Press.

Susetyo, Benny (2004). Hancurnya Etika Politik. Jakarta: Penerbit Buku Kompas.

Ubaidillah, A et al (2000). Pendidikan Kewarganegaraan (Civic Education): Demokrasi, HAM, \& Masyarakat Madani. Jakarta: IAIN Jakarta Press. 


\section{B. UNDANG-UNDANG DAN PUTUSAN}

Undang-Undang Dasar Negara Republik Indonesia Tahun 1945.

Undang-Undang Nomor 8 Tahun 2015 tentang Perubahan Atas Undang-Undang Nomor 1 Tahun 2015 Tentang Penetapan Peraturan Pemerintah Pengganti UndangUndang Nomor 1 Tahun 2014 Tentang Pemilihan Gubernur, Bupati, Dan Walikota Menjadi Undang-Undang.

Undang-Undang Nomor 10 Tahun 2016 tentang Perubahan Kedua Atas UndangUndang Nomor 1 Tahun 2015 Tentang Penetapan Peraturan Pemerintah Pengganti Undang-Undang Nomor 1 Tahun 2014 Tentang Pemilihan Gubernur, Bupati, Dan Walikota Menjadi Undang-Undang.

Putusan MK-RI Nomor Perkara 17/PUU-VI/2008.

Putusan MK-RI Nomor Perkara 33/PUU-XIII/2015.

Risalah Sidang MK-RI Perkara Nomor 60/PUU-XIV/2016.

\section{INTERNET}

http://www.dpr.go.id/doksetjen/dokumen/minangwan-seminar-Analisa-KritisTerhadap-Perpu-No-1-Tahun-2004-Tentang-Pemilihan-Gubernur-Bupati-danWalikota-1435282892.pdf http://megapolitan.kompas.com/read/2016/10/26/17080951/jika.uji.materi.cuti. kampanye.dikabulkan.mk.ahok.akan.bekerja.lagi http://sains.kompas.com/read/2016/10/07/09520321/perdebatan.ahok.dan.utus an.jokowi.soal.cuti.kampanye.petahana http://berita.suaramerdeka.com/smcetak/cuti-kampanye-pilkada/ 